\title{
Lower and Middle Jurassic ammonoids of the Shemshak Group in Alborz, Iran and their palaeobiogeographical and biostratigraphical importance
}

Kazem Seyed-Emami, Franz T. Fürsich, Markus Wilmsen, Mahmoud R. Majidifard, and Ali Shekarifard Acta Palaeontologica Polonica 53 (2), 2008: 237-260 doi:http://dx.doi.org/10.4202/app.2008.0206

The Shemshak Group at Shahmirzad (northern Iran) is characterized by the most frequent and extensive marine intercalations and contains the most abundant and diverse ammonite faunas hitherto known from the Lower and lower Middle Jurassic strata of the Alborz Range. So far, 62 ammonite taxa have been recorded from this area, including 25 taxa from earlier studies. The taxa belong to the families Cymbitidae, Echioceratidae, Amaltheidae, Dactylioceratidae, Hildoceratidae, Graphoceratidae, Hammatoceratidae, Erycitidae, and Stephanoceratidae with the new species Paradumortieria elmii and Pleydellia (P.?) ruttneri. The fauna represents the Late Sinemurian, Late Pliensbachian, Toarcian, Aalenian, and Early Bajocian. Palaeobiogeographically, it is closely related to the Northwest European (Subboreal) Province, and exhibits only minor relations with the Mediterranean (Tethyan) Province.

Key words: Ammonitida, biostratigraphy, palaeobiogeography, Jurassic, Shemshak Group, Alborz Mountains, Iran

Kazem Seyed-Emami [kemami@ut.ac.ir] and Ali Shekarifard, School of Mining Engineering, University College of Engineering. University of Tehran, P.O. Box 11365-4563, Tehran, Iran; Franz T.

Fürsich [franz.fuersich@pal.uni-erlangen.de] and Markus Wilmsen [markus.wilmsen@ pal.uni-erlangen.de], Geozentrum Nordbayern der Universität Erlangen-Nürnberg, Fachgruppe PaläoUmwelt, Loewenichstraße 28, D-91054 Erlangen, Germany; Mahmoud R. Majidifard [m majidifard@yahoo.com], Geological Survey of Iran , Box 131851-1494, Tehran, Iran.

This is an open-access article distributed under the terms of the Creative Commons Attribution License (for details please see creativecommons.org), which permits unrestricted use, distribution, and reproduction in any medium, provided the original author and source are credited. 
FoF Full text $(1,426.0 \mathrm{kB})$ 